The first summit to consider health and life matters in NSW was the NSW Drug Summit held in May 1999. The cosmopolitan composition of the summiteers was notable. There were 172 resolutions as a result and an action plan followed with, on average, a million dollars for each resolution! More people with drug problems are now receiving due care. Much remains to be done but a coherent, connected set of services has resulted, with measurable benefit.

A second summit, the NSW Childhood Obesity Summit, held in September 2002, was a similar success. Its aim was to build community consensus about future directions in childhood overweight and obesity prevention policy, and to recommend a future course of action. One immediate outcome has been the creation of the NSW Centre for Overweight and Obesity, funded by the NSW Department of Health. The Centre is initially focusing on reducing obesity in children and adolescents, however its long-term aim is the reduction of obesity in the whole NSW population.

The Forum hopes that you will be inspired by these accounts of where public health effort has made a solid contribution to the health of the people of NSW. These success stories augur well for similar continuing contributions to our state of health. The Forum, through its work plan, seeks to be involved with you, the public health professional out in the field. The Forum intends to keep you informed about our thinking, to involve you in forthcoming planning workshops, and to staying close to you and your concerns.

All good wishes for the remainder of 2003 !

Regular updates about the Forum will be available through the NSW Public Health Bulletin and communiqués from the Forum. Full and summary versions of Healthy People 2005 can be found at the NSW Department of Health website at www.health.nsw.gov.au/health-public-affairs/ publications/healthyppl/index.html.

Comments about the work of the Forum are warmly welcomed and can be made by emailing pvita@doh.health.nsw.gov.au.

\section{REFERENCE}

1. Public Health Division. Healthy People 2005-New Directions for Public Health in NSW. Sydney: NSW Department of Health, 2000.

\title{
THE SYDNEY OLYMPICS: A WIN FOR PUBLIC HEALTH
}

\section{Louisa Jorm}

Centre for Epidemiology and Research

NSW Department of Health

\section{Maria Visotina}

Regional Coordination Program

NSW Premier's Department

The Games of the XXVI Olympiad, held in Sydney in September 2000, were the largest mass sporting event ever held in Australia. The local public health system had considerable experience in providing services for mass events, such as the annual City to Surf fun run and the Sydney Gay and Lesbian Mardi Gras. However, the challenge presented by the Olympic Games far outstripped these events in terms of the expected numbers of local and international visitors, the extended duration of the event (two weeks) and its high profile, which was accompanied by an intense level of public, political and media interest.

NSW Health was responsible for providing public health services for the Sydney 2000 Olympic Games, as well as hospital care, health care interpreters and ambulance services. This article reports how the public health services were developed; describes the services and the issues and incidents that they managed; and discusses the public health legacy of the Games.

\section{THE CHALLENGE}

The major public health issues managed in the three summer Olympic Games held prior to the Sydney Games were heat-related illness, ${ }^{1,3}$ food safety, ${ }^{2,3}$ and bombingrelated injuries resulting from terrorist attack. ${ }^{3}$ In 1997, as part of its planning processes, NSW Health conducted a risk assessment to prioritise public health issues for the Sydney Games. This assessment identified the major risks as: food-borne illness, terrorism (from conventional means), measles, rubella, pertussis, meningococcal and viral meningitis, tuberculosis, sexually transmissible infections, viral haemorrhagic fevers, blood-borne pathogens, water-borne illness, and Legionnaires' Disease. Heat-related illness was considered unlikely to be a major problem in Sydney in September.

Additional risks that were added to this high priority list over the following three years as a result of local and international events included cryptosporidiosis and acts of biological terrorism (bioterrorism). ${ }^{4}$

\section{THE RESPONSE}

Planning for the public health aspects of the Games commenced in late 1994. An expert public health committee (formed in 1996) oversaw the development of a public health action plan. The major components of the 
plan included public health surveillance, food safety, environmental health, health on cruise ships (vessel inspection program), and counter disaster preparedness.

\section{Public health surveillance}

The Olympic Health Surveillance System was the most comprehensive health surveillance system ever established in Australia. Major components included enhanced surveillance of communicable diseases; patient presentations to sentinel emergency departments; medical encounters at Olympic venues; surveillance of cruise ships; environmental and food safety inspections; surveillance for bioterrorism; and global epidemic intelligence. ${ }^{4,5}$ The system provided daily updates from these data sources over a 38-day period, commencing three weeks before the Opening Ceremony and finishing three days after the Closing Ceremony.

\section{Food safety}

The food safety program commenced in 1999 with Operation Foodwatch, a systematic audit of high-volume, tourism-related food outlets in the Sydney greater metropolitan area. In the lead-up to the Games, Departmental officers worked with the core group of nine master caterers appointed by the Sydney Organising Committee for the Olympic Games (SOCOG), to draw up food safety plans. The Department also had input into the hygienic construction and fitout of food premises, especially temporary structures, through ongoing liaison with the Olympic Coordination Authority (OCA). ${ }^{6}$ Throughout the Games, food safety teams at all Olympic venues conducted site inspections and selective sampling and microbiological testing of foods.

\section{Environmental health}

In the two years prior to the Games, the Department, in cooperation with the metropolitan public health units, implemented a broad environmental health program in collaboration with most local councils and a range of state agencies, including OCA, SOCOG, the Environment Protection Authority, and the Sydney Water Corporation. Programs were introduced in the areas of air quality, water quality, clinical waste management, sanitation, vector control, and public health contingency planning.

Each of 47 Olympic sites was inspected prior to competition, and an ongoing environmental health presence was provided within venues during the competition period. ${ }^{7}$

\section{Health on cruise ships (Vessel Inspection Program)}

Ten cruise ships were moored in Sydney Harbour as 'floating hotels' for around three weeks over the Games period, accommodating 3,500 passengers and 2,900 crew at any one time. The vessel inspection program was modelled on the US Centres for Disease Control and Prevention (CDC) Vessel Sanitation Program. Environmental health officers conducted inspections of each cruise ship on arrival, and regularly thereafter, focusing on food buffet services, water supply, waste disposal, air conditioning systems, and swimming pool and spa maintenance. ${ }^{8}$

\section{Counter disaster preparedness}

Prior to the Games, training in awareness for Chemical, Biological, and Radiological (CBR) emergencies took place across NSW. Seven hospital sites developed mass casualty decontamination facilities, with additional procedures implemented at five other hospitals. Protective equipment and pharmaceutical supplies were distributed to the major hospital sites. ${ }^{9}$

NSW HEALTHPLAN, which coordinates all health services under a single command structure in response to major incidents or disasters, was placed on alert for the Games period. This command involved staffing a Health Services Disaster Control Centre, the establishment of rostered Medical Disaster Response Teams and the placement of liaison officers in the Sydney Police Centre.

\section{WHAT HAPPENED DURING THE GAMES?}

Around 11,000 athletes from 200 countries, 5,100 officials, 11,000 media personnel, and 100,000 international visitors converged on Sydney for the Games. Approximately 800 staff delivered public health services.

No outbreaks of communicable diseases were detected, outside the seasonal pattern typical for influenza and pertussis in the resident population of Sydney. ${ }^{4}$

There were around five per cent more presentations to Sydney emergency departments than in comparable periods in other years. In general, the causes for emergency presentation during the Games were similar to the immediate pre-Games period. However, the proportion of presentations for bloody diarrhoea and pneumonia decreased slightly, while the proportion of presentations for illicit drug-related causes increased slightly. During the Games, proportionally more injuries were attributed to being struck by or colliding with a person or object, and to bicycle accidents. Fewer injuries occurred in the work place. Injuries occurred more on beaches or in swimming pools, and in premises licensed to sell alcohol. ${ }^{4}$

Several incidents detected through surveillance prompted further investigation and action. These included injuries caused by broken glass at an Olympic entertainment venue, an increase in emergency presentations for injuries relating to foot-propelled scooters, a cluster of emergency presentations apparently related to the use of the drug ecstasy, and an increase in presentations for gastrointestinal symptoms at one emergency department. ${ }^{4,10,11}$

No outbreaks of food-borne illness were detected. More than one million meals were served at the athletes' village. Food safety officers reported details of almost 6,300 food 
safety inspections of more than 1,000 outlets. Of these, less than one-quarter were rated as unsatisfactory. Offending outlets were issued with warnings and received follow-up inspections. Operators voluntarily destroyed 7.5 tonnes of food after being advised of food safety risks. This included seven tonnes of spoiled food, from a single food outlet, caused by a refrigeration failure. ${ }^{4}$

No outbreaks of disease from environmental causes were detected. Four of the 47 venues that were subject to environmental inspections received 'unsatisfactory' ratings, and these were reported to SOCOG. Around 170 follow-up environmental inspections and 60 pool and spa inspections were carried out to ensure that problems had been rectified. ${ }^{4}$

No public health incidents were associated with the 10 cruise ships berthed in Sydney Harbour. Nine of the 10 ships were given 'satisfactory' ratings upon inspection. The vessel inspection teams identified several environmental and hygiene problems on the remaining ship (which was not regularly used as a passenger liner), prompting warnings and follow-up inspections. ${ }^{4}$

No mass casualty emergencies or incidents suggestive of bioterrorism occurred. However, counter disaster teams responded to several incidents. These included multiple reports of tainted water in one Sydney suburb before the Games, the discovery of suspicious biological material at Sydney Airport, and a chemical leak at Sydney Airport. On closing night, both duty medical teams were deployed to Sydney Hospital to assist in managing health issues associated with major crowding and congestion in the central business district. ${ }^{4}$

\section{THE LEGACY OF THE GAMES}

The success of the public health response for the Games can be attributed to:

- careful planning-detailed planning began five years before the Games, enabling appropriate resources to be identified, systems to be tested, and staff trained;

- the comprehensive and timely public health surveillance system;

- clearly defined lines of reporting and communication to the peak health decision-making body and other relevant agencies.

Many of the public health strategies developed for the Games relied on strong inter-agency collaborations, particularly among the NSW Department of Health, area health services, and other government departments and agencies, especially local councils, OCA and SOCOG. Most of the structures, linkages and strategies that were developed to support public health aspects of the Games will continue. General public health infrastructure in NSW, especially the capacity to effectively manage mass gatherings, will be permanently enhanced.

A description of the public health preparations for the Sydney 2000 Olympic Games was published as an issue of the NSW Public Health Bulletin (Volume 11 , Number 8 ). This can be viewed and downloaded from the Bulletin website at www.health.nsw.gov.au/public-health/phb/ phb.html.

\section{ACKNOWLEDGEMENTS}

The authors wish to acknowledge the contributions of all staff of New South Wales Health and other agencies that were part of the Olympic Games public health effort.

\section{REFERENCES}

1. Weiss BP Mascola L, Fannin SL. Public health at the 1984 Summer Olympics: The Los Angeles County experience. Am J Public Health 1988;78:686-8.

2. Panella H, Plasecia A, Sanz M et al. Evaluation of the epidemiologic surveillance system for infectious diseases at the Barcelona Olympic Games 1992. Gaceta Sanitaria 1995;9:84-90.

3. Meehan P, Toomey KE, Drinnon J, et al. Public Health Response for the 1996 Olympic Games. JAMA 1998;279:1469-73.

4. Jorm LR, Thackway S, Churches T, Hills M. Watching the Games: Public health surveillance for the Sydney 2000 Olympic games. J Epidemiol Community Health 2003;57:102-8.

5. Thackway SV, Delpech VC, Jorm LR, McAnulty JM, Visotina M. Monitoring acute diseases during the Sydney 2000 Olympic and Paralympic Games. Med J Aust 2000;173(6):318-21.

6. Holroyd S, Shields J, Waples P. Food safety management at Olympic venues during the Sydney 2000 Olympic and Paralympic Games. NS W Public Health Bull 2000;11(8):151-2.

7. Banwell K. Environmental health preparation for the Sydney 2000 Olympic and Paralympic Games. NS W Public Health Bull 2000;11(8):147-8.

8. Waples P, Thackway S, Banwell K, Ferson M, Hatzi S. Health surveillance on cruise ships during the Sydney 2000 Olympic and Paralympic Games. N SW Public Health Bull 2000;11(8):150-1.

9. Flynn M. Counter Disaster Planning for the Sydney 2000 Olympic and Paralympic Games. N S W Public Health Bull 2000;11(8):140-2.

10. Jorm L, Thackway V. Foot-propelled scooter injuries during the Sydney 2000 Olympic Games period. Med J Aust 2001;174:480.

11. Indig D, Thackway S, Jorm L, Salmon A, Owen T. Illicit drug-related harm during the Sydney 2000 Olympic Games: implications for public health surveillance and action. Addiction 2003;98:97-102. $\mathrm{g}$ 